\title{
ОРГАНІЗАЦІЯ МЕДИКО-САНІТАРНОЇ ДОПОМОГИ ХВОРИМ НА ХРОНІЧНИЙ ПАНКРЕАТИТ ТА ЇХ РЕАБІЛІТАЦІЯ
}

\author{
Харківський національний медичний університет, м. Харків, Україна
}

\begin{abstract}
Мета: вивчити та охарактеризувати чинники, які зумовлюють якість надання медичної допомоги хворим на хронічний панкреатит та їх реабілітації.

Матеріали і методи. Проведено соціологічне опитування, за розробленими анкетами, 300 хворих на хронічний панкреатит та викопіювання даних із медичної документації: статистичних карт хворих, які вибули зі стаціонару (форма № 066/o).

Результати. Встановлено, що пацієнтам, які хворіють на хронічний панкреатит, недостатньо проводять реабілітаційні заходи, так відсоток охоплення проведеного оздоровлення в санаторії склав лише $(34,7 \pm 2,8) \%$ хворих, недостатність знань із організації харчування, де лише $(50,3 \pm 2,9)$ \% у повному обсязі володіють необхідною інформацією, ранкову гімнастику виконують лише $(64,0 \pm 2,8) \%$, фрізіотерапевтичні методи застосовують тільки $(62,7 \pm 2,8) \%$.

Висновки. Отримані дані підтверджують необхідність оптимізації системи надання медико-проорілактичної допомоги хворим на хронічний панкреатит та їх реабілітації.
\end{abstract}

КЛЮчОВІ СЛОВА: хронічний панкреатит; реабілітація; медико-санітарна допомога.

Організація та вдосконалення медико-санітарної допомоги хворим на хронічний панкреатит та їх реабілітація $€$ актуальним завданням, оскільки забезпечує збереження, зміцнення, покращення стану здоров'я населення, призводить до зниження таких негативних показників, як показники захворюваності, смертності, інвалідності, що знаходить своє відображення в покращенні якості життя населення. Для досягнення завдання зі зміни пріоритету проведення насамперед профрілактичних заходів, а не лікування хворих, в Україні у співпраці з Всесвітньою організацією охорони здоров'я було затверджено Концепцію Загальнодержавної програми «Здоров'я-2020: український вимір». Також в Україні розпорядженням Кабінету Міністрів України від 26 липня 2018 р. № 530-р затверджено Національний план заходів щодо неінфекційних захворювань для досягнення глобальних цілей сталого розвитку.

Диспансеризація відіграє важливу роль в системі організації медичної допомоги хворим на хронічний панкреатит. Якісно організований диспансерний нагляд підвищує ефрективність лікування, знижує частоту рецидивів захворювання. Оскільки у хворих спостерігають структурні зміни підшлункової залози, повного відновлення функцій цього органа не відбувається навіть у період після загострення, тому важливо дотримуватися спадкоємності лікарям стаціонару та поліклініки з подальшим проведенням диспансерного нагляду в амбулаторно-поліклінічних умовах та проведенням реабілітаційних заходів в умовах санаторію [1].

(С) П.О. Трегуб, 2018
У літературі все частіше дослідники ставлять питання щодо необхідності надання психологічної допомоги хворим на хронічний панкреатит. До цього призводять неухильне зростання захворюваності й поширеності хронічного панкреатиту та розвиток загрозливих наслідків як для життя хворого, так і для нормального психосоціального фрункціонування [3].

Кількість непсихотичних психічних розладів серед хворих зростає, у тому числі й серед пацієнтів із хронічним панкреатитом, серед них провідне місце займають розлади тривожно-депресивного спектра, та астено-невротичною симптоматикою, що призводять до виникнення депресивного світосприйняття, що, в свою чергу, негативно впливає на результати лікування та проведення реабілітаційних заходів [4].

Проведення реабілітаційних заходів для хворих на хронічний панкреатит відіграє важливу роль в системі надання лікувально-профілактичної допомоги. У сучасних умовах медична реабілітація це комплекс лікувальних заходів, що спрямовані на відновлення та розвиток фрізіологічних фрункцій хворого з метою його адаптації до нових умов, що виникли внаслідок захворювання [2].

Мета дослідження: вивчити та охарактеризувати чинники, які зумовлюють якість надання медичної допомоги хворим на хронічний панкреатит та їх реабілітації.

Матеріали і методи. Проведено соціологічне опитування, за розробленими анкетами, 300 хворих на хронічний панкреатит та викопіювання даних із медичної документації: статистичних карт хворих, які вибули зі стаціонару (форма № 066/о). 
Результати дослідження та їх обговорення. Основним завданням первинної ланки надання медичної допомоги $€$ рання діагностика та лікування захворювання. Відомо, що вчасно та якісно надана первинна допомога дозволяє в рази покращити прогноз та знизити ймовірність розвитку ускладнень. За даними дослідження, на етапі надання первинної медичної допомоги хворим на хронічний панкреатит за останні 12 місяців кількість візитів через прояви цього захворювання здійснено до дільничного терапевта (сімейного лікаря) в середньому 3,6 раза, жодного разу $(19,3 \pm 2,3) \%, 1-3$ рази $(17,3 \pm 2,2) \%, 4$ рази та більше $(63,0 \pm 2,8) \%$. При цьому для планового контролю захворювання в середньому 2 рази, жодного $(20,3 \pm 2,3) \%, 1-3$ рази $(70,3 \pm 2,6) \%, 4$ та більше $(9,7 \pm 1,7) \%$.

До лікаря-гастроентеролога за останні 12 місяців кількість візитів через прояви захворювання на хронічний панкреатит здійснено в середньому 2,4 раза, жодного разу $(22,0 \pm 2,4) \%, 1-3$ рази $(53,0 \pm 2,9) \%, 4$ рази $(25,0 \pm 2,5) \%$. Для планового контролю захворювання в середньому 1,3 рази, жодного разу $(26,0 \pm 2,5) \%, 1-3$ рази $(74,0 \pm 2,5) \%$.

Після встановлення діагнозу «хронічний панкреатит» хворого відповідно до Унісрікованого клінічного протоколу первинної, вторинної (спеціалізованої) медичної допомоги та медичної реабілітації необхідно направити до лікаря-гастроентеролога для підтвердження діагнозу. Було направлено $(82,7 \pm 2,2) \%$ опитаних, не направленими виявились $(17,3 \pm 2,2) \%$.

Важливу роль в ефрективності лікування хронічного панкреатиту відіграє якісний диспансерний облік. За отриманими результатами дослідження, диспансерному обліку підлягають $(70,7 \pm 2,6) \%$, не підлягають $(29,3 \pm 2,6) \%$. Серед тих, хто перебуває на диспансерному обліку в лікаря-гастроентеролога $(64,2 \pm 3,3) \%$, а у дільничного терапевта (сімейного лікаря) $(35,8 \pm 3,3) \%$.

Розробка та надання пацієнту письмових рекомендацій про те, як необхідно стежити за здоров'ям при хронічному панкреатиті має значення для позитивного результату лікування, відновлення та запобігання ускладнень. Так, $(71,3 \pm 2,6)$ \% вони наявні, не мають рекомендацій $(28,7 \pm 2,6) \% .3$ тих, хто має письмові рекомендації від лікаря-гастроентеролога $(63,1 \pm 3,3) \%$, дільничного терапевта (сімейного лікаря) $(35,0 \pm 3,3) \%$, лікаря стаціонару $(1,4 \pm 0,8) \%$ та лікаря-хірурга поліклініки $(0,5 \pm 0,5) \%$. Необхідно відзначити, що про наявність усних рекомендацій відповіли позитивно $(99,7 \pm 0,3) \%$ опитаних.

Для успішного лікування важливим $€$ те, який прогноз пацієнт має щодо свого захворювання. Отримані дані не дозволяють говорити про позитивність такого важливого показника, так що прогноз благонадійний визначили $(15,7 \pm 2,1) \%$, неблагонадійний - $(29,7 \pm 2,6) \%$, не визначились - $(54,7 \pm 2,9) \%$. Значно покращити наведені показники та, що більш важливо, змінити ставлення до цього тяжкого захворювання, що часто призводить до виникнення страху за життя, $є$ робота зі психологом. За даними дослідження, було рекомендовано звернутися до психолога $(13,0 \pm 1,9) \%$, при цьому $(87,0 \pm 1,9) \%$ опитаних такої рекомендації не отримали. До психолога звернулись $(11,3 \pm 1,8) \%$, а $(88,7 \pm 1,8)$ \% залишилися без психологічної допомоги. Покращення свого психологічного стану після роботи зі психологом відзначили $(85,3 \pm 2)$ \% 3 тих, хто звернувся до нього. При цьому більшість з опитаних $(52,7 \pm 2,9)$ \% має бажання та необхідність в психологічній допомозі, відповідно, $(47,3 \pm 2,9)$ \% відзначили, що такої необхідності не мають.

Важливим при наданні медико-профрілактичної допомоги населенню $є$ підвищення рівня гігієнічної культури, залучення його широких верств до процесу зміцнення здоров'я шляхом формування здорового способу життя, що дозволяє в рази покращити результати надання допомоги населенню, у тому числі й хворим на хронічний панкреатит. Такі завдання виконують центри здоров'я. Так, $(15 \pm 2,1) \%$ зверталися до центрів здоров'я, відповідно, $(85 \pm 2,1) \%$ такої можливості не мали. 3 тих, хто звертався в цей заклад $(97,8 \pm 2,2) \%$ відзначають надання їм допомоги, допомоги не отримали $(2,2 \pm 2,2) \%$. Але всі зазначають про виконання ними рекомендацій, отриманих у центрі здоров'я.

Бригадою швидкої медичної допомоги було доставлено $(69,3 \pm 2,7)$ \% опитаних, іншими шляхами - $(30,7 \pm 2,7) \%$. Отримано дані щодо часу приїзду швидкої: $10-30$ хв $(96,7 \pm 1,2) \% ; 30-60$ хв $(2,9 \pm 1,2) \%$; більше 1 год $(0,5 \pm 0,5) \%$. Першу допомогу надавав лікар швидкої $(86,1 \pm 2,4) \%$, допомога не надавалася $(13,9 \pm 2,4) \% 3$ тих, хто викликав швидку. Покращення свого стану відзначають $(65,9 \pm 3,3) \%$, а відсутність покращення $(34,1 \pm 3,3) \%$ після надання допомоги лікарем швидкої.

Оскільки важливо вчасно надати допомогу 3 моменту погіршення стану та госпіталізувати при потребі хворого, можна відзначити, що $(47,7 \pm 2,9) \%$ були госпіталізовані через 5-10 год із моменту погіршення, $(45,7 \pm 2,9) \%$ до 5 год та $(6,7 \pm 1,4) \%$ після того, як пройшло 10 год та більше.

Необхідно навчити пацієнта самостійно попереджувати загострення захворювань, а особливо це стосується хронічного панкреатиту. 3 огляду на це, $(70,3 \pm 2,6) \%$ знають як це зробити, а $(29,7 \pm 2,6) \%$ - ні. При чому $(91,7 \pm 1,6) \%$ мають письмовий план приймання лікарських засобів у період загострення, а $(8,3 \pm 1,6) \%$ - не мають. При загостренні, що призвело до госпіталізації в стаціонар, письмовий план приймання лікар- 
ських засобів мали при собі $(76,7 \pm 2,4) \%$, не мали - $(23,3 \pm 2,4) \%$.

Загострення, що призвело до госпіталізації хворого в стаціонар лікарні, розпочалося вдома у $(72,3 \pm 2,6) \%$, на робочому місці в $(17,7 \pm 2,2) \%$, на вулиці - $(7,0 \pm 1,5) \%$, в іншому місці - $(3,0 \pm 1,0) \%$. Залежно від часу це сталося зранку в $(22,7 \pm 2,4) \%$, вдень - у $(44,7 \pm 2,9) \%$, ввечері - у $(21,7 \pm 2,4) \%$, вночі - у $(11,0 \pm 1,8) \%$. Для зменшення симптомів хворі мають приймати ліки і $(68,7 \pm 2,7) \%$ опитаних ліки приймали, але покращення не настало, $(14,0 \pm 2) \%$ ліків із собою при загостренні не мали, $(1,3 \pm 0,7)$ \% відзначають, що в аптеці ліки були відсутні, а $(6,7 \pm 1,4) \%$ - не купили. У домашній аптечці є ліки, що необхідні при загостренні у $(78,7 \pm 2,4) \%$, немає - у $(21,3 \pm 2,4) \%$ опитаних.

У стаціонар лікарні хворі на хронічний панкреатит були доставлені машиною швидкої медичної допомоги у $(70,3 \pm 2,6) \%$ випадках, самозвернення склало $(24,3 \pm 2,5) \%$, за направленням дільничного терапевта (сімейного лікаря) $(3,3 \pm 1,0) \%$ та за направленням лікаря-гастроентеролога $(2,0 \pm 0,8) \%$.

За останні 12 місяців кількість госпіталізацій 3 приводу захворювання на хронічний панкреатит, за результатами опитування, така: жодної - у $(40,7 \pm 2,8) \%$, одна - у $(21,0 \pm 2,4) \%, 2$ у $(36,7 \pm 2,8) \%, 3$ та більше - в $(0,7 \pm 0,5) \%$.

У реабілітації пацієнтів із хронічним панкреатитом важливе місце займає санаторно-курортне відновлення. При цьому відповідно до Уніфікованого клінічного протоколу первинної, вторинної (спеціалізованої) медичної допомоги та медичної реабілітації санаторно-курортному лікуванню підлягають хворі на хронічний панкреатит у фразі ремісії або нестійкої ремісії. Так, $(58,0 \pm 2,9) \%$ було рекомендовано оздоровитися в санаторії, $(42,0 \pm 2,9) \%$ такої рекомендації не отримали. Реабілітацію в санаторії пройшли $(34,7 \pm 2,8) \%$ хворих, не проходили - $(65,3 \pm 2,8) \%$. Серед тих, хто пройшов санаторно-курортне лікування, позитивний ефект для власного здоров'я отримали $(98,1 \pm 1,3) \%$, відсутність такого - у $(1,9 \pm 1,3) \%$.

Оскільки, крім санаторно-курортного лікування, хворим на хронічний панкреатит обов'язково необхідно стежити за харчуванням, $(98,7 \pm 0,7) \%$ дотримуються дієти, а $(1,3 \pm 0,7) \%$ - не дотримуються. При цьому $(20,0 \pm 2,3)$ \% вказують, що добре знають про наслідки, які будуть, якщо не лікуватися та не дотримуватися дієти, частково знають $(72,7 \pm 2,6) \%$, не знають - $(4,7 \pm 1,2) \%$ пацієнтів. Як правильно організувати прийом їжі відзначають, що знають в повному обсязі $(50,3 \pm 2,9) \%$, частково знають - $(47,7 \pm 2,9) \%$, не знають - $(2,0 \pm 0,8) \%$.

Рекомендовану мінеральну воду вживають $(90,0 \pm 1,7) \%$, не вживають - $(10,0 \pm 1,7)$ \%. Ранкову гімнастику виконують $(64,0 \pm 2,8) \%$, не виконують - $(36,0 \pm 2,8) \%$. Фізіотерапевтичні методи застосовують $(62,7 \pm 2,8) \%$, не застосовують $(37,3 \pm 2,8)$ \% опитаних.

Довіра до лікаря, який надає медичну допомогу, відіграє важливу роль при лікуванні хворого, так $(66,7 \pm 2,7)$ \% повністю довіряють лікарю, який

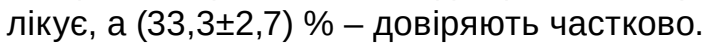

Питання задоволеності пацієнта, отриманою медичною допомогою, на різних етапах її надання вкрай актуальне. Так, при наданні допомоги вдома лікарями швидкої медичної допомоги були отримані такі дані: задоволеними були $(22,6 \pm 2,9)$ \%, частково задоволеними - $(73,1 \pm 3,1) \%$, не задоволеними - $(4,3 \pm 1,4)$ \%. У приймальному відділенні роботою лікаря цього відділення при госпіталізації задоволені $(43,0 \pm 2,9) \%$, частково задоволені - $(55,7 \pm 2,9) \%$, не задоволені - $(1,33 \pm 0,7) \%$. Роботою лікаря стаціонару повністю задоволені $(80,0 \pm 2,3) \%$, частково задоволені - $(19,0 \pm 2,3) \%$, не задоволені - $(1,0 \pm 0,6) \%$.

В опитуванні також було запропоновано оцінити за 10-бальною шкалою задоволеність організацією діагностичного процесу, лікувального процесу та санітарно-побутовими умовами перебування у стаціонарі. щодо задоволеності організацією діагностичного процесу отримані такі дані: 3-5 балів надали $(2,3 \pm 0,9) \%, 6-8$ балів $(28,7 \pm 2,6) \%, 9-10$ балів - $(69 \pm 2,7) \%$ опитаних. Задоволеність організацією лікувального процесу: 5-6 балів надали $(2,0 \pm 0,8) \%, 7-8$ балів $(22,0 \pm 2,4) \%, 9-10$ балів - $(76,0 \pm 2,5) \%$. Санітарно-побутові умови перебування в стаціонарі: 4-6 балів надали $(29,7 \pm 2,6) \%, 7-8$ балів $(48,3 \pm 2,9) \%, 9-10$ балів - $(22,0 \pm 2,4) \%$.

Лікування хронічного панкреатиту доволі затратне та створює відчутне фрінансове навантаження як на пацієнта, так і на його родину. На жаль, лише $(17,0 \pm 2,2) \%$ вказують на те, що мають можливість придбати всі лікарські препарати, що необхідні для лікування. Відповідно $(83,0 \pm 2,2) \%$ у повному обсязі такої можливості не мають. Якщо аналізувати за відсотками, то 30 та менше відсотків ліків може купити $(25,0 \pm 2,5) \%, 30-$ $50-(41,0 \pm 2,8) \%, 50-(15,3 \pm 2,1) \%$ та $75-100-$ $(18,7 \pm 2,3) \%$ опитаних пацієнтів.

Інфрормаційна обізнаність пацієнта в питаннях приймання ліків, побічних ефректів від їх приймання, механізму їх дії, $€$ важливою, оскільки дозволяє розуміти необхідність їх приймання. Серед опитаних $(44,3 \pm 2,9) \%$ повною мірою знають коли необхідно приймати ліки, частково знають $(53,0 \pm 2,9) \%$, не знають - $(2,7 \pm 0,9) \%$. Про побічні еоректи від приймання ліків повністю знають $(3,3 \pm 1,0) \%$, частково знають - $(59,3 \pm 2,8) \%$, не знають - $(37,3 \pm 2,8) \%$. Механізм дії ліків знають повністю $(2,0 \pm 0,8) \%$, частково - $(39,0 \pm 2,8) \%$, не знають - $(59,0 \pm 2,8) \%$ опитаних.

Длябільшдетальноговивченнянаданнястаціонарної допомоги хворим на хронічний панкреатит 
у ході цього дослідження було проаналізовано 358 статистичних карт хворих, які вибули зі стаціонару (форма № 066/o). За отриманими даними, екстрена госпіталізація була у $(39,8 \pm 2,6) \%$ випадках, планова - у $(60,2 \pm 2,6) \%$. При цьому строки госпіталізації до 6 год у $(6,3 \pm 1,4) \%, 7-24$ год -у $(26,7 \pm 2,5) \%$, більше 24 год - у $(67,0 \pm 2,6) \%$ випадках госпіталізації. Вперше цього року по цьому захворюванню госпіталізовані $(88,7 \pm 1,7) \%$, повторно - $(11,3 \pm 1,7)$ \% хворих. Шляхом самозвернення були госпіталізовані $(82,7 \pm 2,0)$ \% пацієнтів, бригадою швидкої медичної допомоги $(13,7 \pm 1,8) \%$, а за направленням інших медичних закладів - $(3,6 \pm 1,0)$ \%. Кількість проведених ліжко-днів: 1-5 днів - у $(18,8 \pm 2,1) \%$ випадках, 6-10 - у $(35,0 \pm 2,5) \%, 11-15-$ у $(27,5 \pm 2,4) \%, 16-$ 20 - у $(13,7 \pm 1,8) \%$, більше 20 - $(5,0 \pm 1,2) \%$ випадках госпіталізації. Хірургічне втручання при цій госпіталізації було проведено у $(8,1 \pm 1,4) \%$, не проводилося - у $(91,9 \pm 1,4) \%$. За результатами лікування, відсоток виписаних здоровими $(0,3 \pm 0,3) \%$, з поліпшенням стану - $(90,1 \pm 1,6) \%$, без змін - $(2,6 \pm 0,9) \%$, а $з$ погіршенням стану $(0,6 \pm 0,4) \%$.

\section{Висновки}

1. Виявлено практично повне ігнорування психологічної допомоги хворим на хронічний панкреатит, де звернулися до психолога лише $(11,3 \pm 1,8) \%$ з опитаних, з них $(85,3 \pm 2,0)$ \% відзначають покращення після спілкування з психологом, а прогноз власного стану як неблагонадійного - $(29,7 \pm 2,6)$ \%. При цьому $(52,7 \pm 2,9) \%$ прагнуть такого спілкування, якби була така можливість.

2. Відзначено низький відсоток охоплення хворих на хронічний панкреатит диспансерним обліком, так лише $(70,7 \pm 2,6) \%$, що $є$ недостатнім рівнем динамічного спостереження за здоров'ям хворих. При цьому, в $(28,7 \pm 2,6) \%$ не має розроблених рекомендацій про те, як ви повинні стежити за здоров'ям при хронічному панкреатиті.

3. Виявлено практично відсутність в організації медико-профрілактичної допомоги хворим на хронічний панкреатит закладів, які забезпечують підвищення рівня гігієнічної культури, залучення його широких верств до процесу зміцнення здоров'я шляхом формування здорового способу життя, що дуже важливо проводити при хронічному панкреатиті, а саме центрів здоров'я. Так, лише $(15 \pm 2,1)$ \% опитаних звернулися в центр здоров'я.

4. Встановлено, що лікування хронічного панкреатиту несе відчутне фінансове навантаження на бюджет пацієнта та його родини. За отриманими даними, $(83,0 \pm 2,2)$ \% в повному обсязі не мають можливості придбати всі лікарські препарати, що необхідні для лікування, що, в свою чергу, значно знижує ефрективність надання медикопрофрілактичної допомоги.

5. Встановлено, що пацієнтам, які хворіють на хронічний панкреатит, недостатньо проводять реабілітаційні заходи, так відсоток охоплення проведеного оздоровлення в санаторії склав лише $(34,7 \pm 2,8)$ \% хворих, відповідно, не проходили $(65,3 \pm 2,8) \%$, недостатність знань із організації харчування, де лише $(50,3 \pm 2,9)$ \% в повному обсязі володіють необхідною інформацією, ранкову гімнастику виконують лише $(64,0 \pm 2,8) \%$, фрізіотерапевтичні методи застосовують тільки $(62,7 \pm 2,8) \%$, що свідчить про необхідність удосконалення системи реабілітації хворих на хронічний панкреатит.

Перспективи подальших досліджень. Отримані, в результаті проведеного дослідження, дані дають можливість оптимізувати систему надання медико-профрілактичної допомоги хворим на хронічний панкреатит та їх реабілітації.

\section{Список літератури}

1. Белякова С. В. Оценка качества амбулаторного лечения / С. В. Белякова, Е. А. Белоусова // Медицинский совет. - 2014. - № 13. - C. 46-48.

2. Бондаренко О. А. Современные возможности медицинской реабилитации больных хроническим панкреатитом на фроне ожирения / О. А. Бондаренко, Ф. Ю. Мухарлямов // Вестник Национального медико-хирургического центра им. Н. И. Пирогова. - 2013. - Т. 8, № 1. - С. 87-90.

3. Удовлетворенность медицинской помощью: как измерить и сравнить? / О. С. Кобякова, И. А. Деев, Д. С. Тюфилин [и др.] // Социальные аспекты здоровья населения. - 2016. - Т. 49, № 3.- С. 1-14.

4. Шевченко Ю. М. Клініко-психопатологічні особливості непсихотичних психічних розладів у хворих на хронічний панкреатит / Ю. М. Шевченко // Український вісник психоневрології. - 2014. - Т. 22, Вип. 4. - С. 118-121.

\section{References}

1. Belyakova, S.V., \& Belousova, E.A. (2014). Otsenka kachestva ambulatornogo lecheniya [Quality assessment of outpatient treatment]. Meditsinskiy sovet - Medical Advice, 13, 46-48 [in Russian].

2. Bondarenko, O.A., \& Mugarlyamov, F.Yu. (2013). Sovremennye vozmozhnosti meditsinskoy reabilitatsii bolnykh khronicheskim pankreatitom na fone ozhireniya [Modern possibilities of medical rehabilitation of patients with chronic pancreatitis on the background of obesity]. Vestnik Natsionalnogo mediko-khirurgicheskogo tsentra im. N. I. Pirogova Journal of the National Medical and Surgical Center by N.I. Pirogov, 8 (1), 87-90. 
3. Kobyakova, O.S., Deev, I.A., \& Tyufilin, D.S. (2016). Udovletvorennost meditsinskoy pomoshchyu: kak izmerit i sravnit? [Satisfaction regarding medical aid: how to measure and compare?]. Sotsialnyye aspekty zdorovya naseleniya - Social Aspects of Health of Population, 49 (3), 1-14 [in Russian].

4. Shevchenko, Yu.M. (2014). Kliniko-psykhopatolohichni osoblyvosti nepsykhotychnykh psykhichnykh rozladiv u khvorykh na khronichnyi pankreatyt [Clinical psychopatological non-psychotic psychic disorders in patients with chronic pancreatitis]. Ukrainskyi visnyk psykhonevrolohii - Ukrainian Journal of Psychoneurology, 22 (4), 118-121 [in Ukrainian].

\section{ОРГАНИЗАЦИЯ МЕДИКО-САНИТАРНОЙ ПОМОЩИ БОЛЬНЫМ ХРОНИЧЕСКИМ ПАНКРЕАТИТОМ И ИХ РЕАБИЛИТАЦИЯ \\ П.О. Трегуб \\ Харьковский национальный медицинский университет, г. Харьков, Украина}

Цель: изучить и охарактеризовать фракторы, которые обусловливают качество оказания медицинской помощи больным хроническим панкреатитом и их реабилитации.

Материалы и методы. Проведен социологический опрос, по разработанным анкетам, 300 больных хроническим панкреатитом и выкопировки данных из медицинской документации: статистических карт, выбывших из стационара (форма № 066/y).

Результаты. Установлено, что пациентам, страдающим хроническим панкреатитом, недостаточно проводят реабилитационные мероприятия, так процент охвата проведенного оздоровления в санатории составил лишь $(34,7 \pm 2,8)$ \% больных, недостаточность знаний по организации питания, где только $(50,3 \pm 2,9)$ \% в полном объеме владеют необходимой инорормацией, утреннюю гимнастику делают лишь $(64,0 \pm 2,8) \%$, сризиотерапевтические методы применяют только $(62,7 \pm 2,8) \%$.

Выводы. Полученные данные подтверждают необходимость оптимизации системы оказания медико-профилактической помощи больным хроническим панкреатитом и их реабилитации.

КЛЮЧЕВЫЕ СЛОВА: хронический панкреатит; реабилитация; медико-санитарная помощь.

\section{ORGANIZATION OF HEALTH CARE FOR PATIENTS WITH CHRONIC PANCREATITIS AND THEIR REHABILITATION \\ P.O. Trehub}

Kharkiv National Medical University, Kharkiv, Ukraine

Purpose: to study and characterize the factors that determine the quality of medical care and rehabilitation of patients with chronic pancreatitis.

Materials and Methods. A sociological poll was conducted on the developed questionnaires of 300 patients with chronic pancreatitis and the copying of data from medical records: statistical cards left from the hospital (f. 066/o).

Results. It has been established that patients suffering from chronic pancreatitis are not adequately rehabilitated, so the percentage of coverage of the health improvement in the sanatorium was only $(34.7 \pm 2.8) \%$ of patients, insufficient knowledge of catering, where only $(50.3 \pm 2.9) \%$ volume own the necessary information, morning exercises are only (64.0 \pm 2.8$) \%$, physiotherapy methods apply only $(62.7 \pm 2.8) \%$.

Conclusions. The data obtained confirm the need to optimize the system of medical and preventive care and rehabilitation of patients with chronic pancreatitis.

KEY WORDS: chronic pancreatitis; rehabilitation; health care.

Рукопис надійшов до редакції 20.06.2018 p.

\section{Відомості про автора:}

Трегуб Павло Олегович - аспірант кафредри громадського здоров'я та управління охороною здоров'я Харківського національного медичного університету; тел.: +38(096) 664-70-90. 